Published in: Frank Wijen, Kees Zoeteman, and Jan Pieters (eds), A handbook of globalisation and environmental policy: National government interventions in a global arena, Edward Elgar, Cheltenham, 2005, pp. 1-29.

\title{
1. Globalisation and National Environmental Policy: An Overview
}

\author{
Kees Zoeteman, Frank Wijen, and Jan \\ Pieters $^{1}$
}

\section{SUMMARY}

After outlining the scope, target audience, and structure of the book, we review the literature on globalisation and environmental policy, especially the impact of globalisation on the environment and changes in environmental governance in relation to increasingly global spheres of influence. This is followed by a succinct representation of the essential points of all contributions to this volume. While each chapter has its own distinct focus and perspective, common themes have been identified in major outcomes and future directions: the delicate and multifaceted relation between economic globalisation and environmental protection, changes in the prioritisation of environmental issues, shifts in governance mechanisms, dealing with reduced sovereignty, prospects for existing and new policy instruments, and finding a balance between globalisation and national environmental policy. These findings lead to conclusions with respect to the commensurability of different governance levels and the compatibility of different policy areas.

\section{INTRODUCTION}

In contemporary history, national governments have fulfilled a central role in governance. They are the highest authorities in relatively sovereign states,

We are indebted to Paul Dekker and Paul van Seters for their constructive comments on an earlier version. 
developing national policies and implementing them through lower governmental bodies such as provinces and municipalities. Yet, the authority of national governments has come under pressure. Foreign spheres of influence have constrained governments' external sovereignty: supranational institutions such as the World Trade Organization (WTO) and the European Union (EU) prescribe a significant and increasing number of national regulations. At the same time, governmental authority has been eroded 'from below'. Companies that are 'footloose' because of their presence in a multitude of countries - and whose turnover may exceed the gross product of national economies - may pressurise governments to obtain favourable treatment, while domestic firms may lobby their governments to avoid regulations with adverse international competitive effects. Through telecommunication and imports, for example, citizens and consumers have easy access to foreign cultures and their artefacts and connect more easily with citizens abroad, especially through the internet. This widening scope for citizens and the intensifying interference of supranational institutions with civic issues have often widened the gap between citizens and ruling authorities.

This phenomenon of globalisation is particularly apparent in the domain of environmental policy. For example, a large majority of national environmental regulations in the EU consists of implementing directives from Brussels, where the European Commission (EC) resides, while the WTO has bounded national environmental policies. This can be understood against the backdrop of cross-boundary environmental problems, calling for higher-level interventions, and the possible impact of environmentally inspired government interventions on other policy areas, in particular, a common European market or global market. Multinational companies, both driving and thriving on more global economic exchanges, may play different national governments off against one another to obtain lenient environmental regulations or, conversely, may apply stringent environmental standards required for one market around the globe. The environmental conditions under which imported products have been produced are generally not transparent to consumers, hampering their well-informed decision-making. And citizens may boycott - or otherwise campaign against - foreign or multinational companies they perceive as 'dirty'.

The arena in which national governments operate, therefore, has undergone important changes, which may have reduced the effectiveness of formerly well-functioning environmental policies. The increasingly global or regional spheres of influence may call for a reconsideration of policy instrument in order to be in a better position to meet the novel opportunities and constraints that national governments presently face. The central aim of this book is to 
improve our understanding of the impact of global spheres of influence on the scope of national environmental policies, and to explore effective policy responses to these new opportunities and threats. A better understanding of these interactions may lead to more enlightened visions and better management of power relations.

While many salient publications on the relations between national environmental policy and economic globalisation have appeared, either their scope tends to be limited to specific aspects or their perspective tends to be biased. Our purpose was to provide a comprehensive book on the interface of globalisation and national environmental policy, addressing the impact of the actors and factors shaping globalisation on the scope of action for national environmental policy-makers. The book means to be broad in scope by covering all major aspects, multiple in level of analysis by incorporating macro-, meso-, and micro-levels, heterogeneous in perspectives by representing diverging social viewpoints, and complementary as to disciplines by drawing on insights from economics, law, sociology, political science, public administration, and environmentology. We also aimed to obtain in-depth insights. We were interested both in conceptual contributions pushing back the theoretical frontier and in new case studies providing detailed insights into specific issues. Leading experts from academia, supranational organisations, government, business, and non-governmental organisations (NGOs) were invited to write original contributions on relevant aspects.

Besides providing a comprehensive account of our subject, we were also interested in identifying the degree of commensurability between different levels of influence (global, regional, national, and local) as well as the compatibility of different areas (economic development, jurisdictional competence, political discretion, and environmental protection). Clarifying the tensions between regional or global spheres of influence, on the one hand, and national or local forces, on the other, helps us to address the question whether existing national environmental policies and instruments are commensurable with the opportunities and threats presented by globalisation. Teasing out the compatibility and prioritisation of economic and environmental imperatives against the backdrop of existing legal and political structures is also crucial to understanding what lies within and what lies beyond the bounds of the possible in environmental policies. National governments that wish to design effective environmental policies should consider the options and constraints of the different areas. The present book aims to shed some light on actual and potential governance mechanisms and policy instruments in the environmental field that reflect the changes in the distribution of powers brought about by economic, political, and social globalisation. 
While the book aims to provide the reader with both breadth and depth, it has been designed predominantly from the perspective of a medium-sized 'developed' country. As a result, all 43 authors originate from Europe and North America, and the setting of many case studies is Europe, with an emphasis on the Netherlands. This is partly related to the relatively advanced status of environmental policies in these regions, but it has obviously led to a Western bias.

The book's targeted audience is primarily academics and policy-makers. It may be useful for students and scholars, both newcomers who wish to obtain a comprehensive overview and those with advanced knowledge who wish to obtain a deeper understanding of specific issues. Policy-makers in international and supranational organisations, national and local governments, companies and trade associations, and NGOs may use it as a source of inspiration for future policies. The book obviously targets those interested in environmental problems, though there may be close parallels with social issues. While its scope is international, this book may also be relevant to readers concerned with domestic areas of interest, as these are increasingly exposed to foreign influences.

Turning to the theoretical embedding of the book, we now review literature dealing with the key issues of globalisation, national environmental policies, and governance, including their interrelations. As these issues are addressed extensively throughout the book, the literature review is succinct. Then we outline the structure of the book and the main points of each individual chapter. Finally, we pull the diversity of insights together by identifying and discussing commonalities in the variety of contributions.

\section{THEORETICAL ISSUES}

For centuries, the fates of many nation states have been intertwined. Foreign military interventions, migration, and international trade have long histories. ${ }^{2}$ The degree of interconnectedness has fluctuated over time, with eras of relative isolation and autarky altering with periods of more intensive international interactions. ${ }^{3}$ Over the past few decades, political developments - including the collapse of communist regimes and the elimination of trade barriers - and technological innovations - especially in the fields of transport and communication - have paved the way for increased internationalisation of economic, political, and cultural activities, leading to the (perceived)

2 Hobsbawm, 1975; Landes, 1998; Lechner and Boli, 2000; McNeill and McNeill, 2003; Schaeffer, 2003.

3 Baker et al., 1998; Frankel, 2000; McNeill and McNeill, 2003; Reinicke, 1998; Scholte, 2000; Waters, 2001. 
compression of space and time and the emergence of relational networks at the global level. ${ }^{4}$ Globalisation has many facets, ${ }^{5}$ though the economic dimension has been discussed most often. During the 1990s, international economic transactions (in particular, international trade and foreign investment) rose exponentially, ${ }^{6}$ though internationalisation is spread unevenly: many activities take place within or between regional clusters such as parts of Europe, North America, and Japan. ${ }^{7}$ In the academic literature, the economic and political interdependence of states has long been recognised, ${ }^{8}$ though literature on globalisation witnessed an upsurge in the 1990s. ${ }^{9}$ Some authors highlight the amenities of economic globalisation, in terms of enhanced choice and lower prices of products as well as higher national incomes. ${ }^{10}$ Others argue that globally unleashed market forces have caused or enhanced many social evils, such as increased income inequality and infringement of sovereignty and democracy. ${ }^{11}$

The human impact on the natural environment rose dramatically with the expansion of economic activities, ${ }^{12}$ though there are substantial differences between countries as to their claims on natural resources and pollution of the environment. ${ }^{13}$ Sensitised by alarming publications about the depletion of natural resources and environmental degradation ${ }^{14}$ and by popular concerns for the visible environmental consequences of industrialisation (such as air, water, and soil pollution), national governments in Western countries started developing environmental policies (i.e., strategic courses of action to solve or contain problems related to ecological resources and systems) from the 1970s onwards. Environmental policy issues appeared prominently on the academic agenda in the 1980s, and the field flourished from the 1990s onwards. ${ }^{15}$ In the economics literature, environmental issues are classic examples of externalities because costs and benefits accrue to different parties. ${ }^{16}$ Likewise, collective action is hampered because individual actors lack adequate information or do not have the incentives to protect common

4 Anheier et al., 2001; Castells, 1996; Held, 2004; Inglehart, 1997; Lechner and Boli, 2000; Waters, 2001.

5 Schaeffer, 2003; Scholte, 2000; Waters, 2001.

6 Esty and Gentry, 1997; Frankel and Rose, 2002.

7 Dunning, 2000; Ohmae, 1995; Rugman, 2001.

8 Hobsbawm, 1975; Keohane and Nye, 1977; Wallerstein, 1974, 1980.

9 For overviews, see: Lechner and Boli, 2000; Levy-Livermore, 1998; Michie, 2003.

${ }^{10}$ Bhagwati, 2002; Moore, 2003; Norberg, 2003.

${ }^{11}$ Hertz, 2001; Klein, 2000; Landes, 1998; Mullard, 2004; Stiglitz, 2002; Van Seters et al., 2003.

12 EEA, 2003; UNEP, 2003; Wackernagel and Rees, 1996.

${ }^{13}$ World Economic Forum, 2002.

${ }^{14}$ Carson, 1962; Meadows et al., 1972.

${ }^{15}$ For overviews, see: Bromley, 1995; Lesser et al., 1997; Mäler and Vincent, 2003; Sutherland, 2000; Tietenberg et al., 1999; Van den Bergh, 1999, 2002.

${ }^{16}$ Lesser et al., 1997; Tietenberg, 2003. 
environmental goods. ${ }^{17}$ The protection of natural resources also faces legal problems, especially in transboundary and international settings. ${ }^{18}$

Interactions between globalisation, on the one hand, and environmental issues and national policies, on the other, have also been widely documented. The impact of economic globalisation on the natural environment has been studied extensively. ${ }^{19}$ Positive effects have been framed in terms of the use of environmentally less harmful products and processes, often associated with income rises as a consequence of international specialisation and trade. Negative effects are primarily defined in terms of scale: the use of natural resources and pollution increase when economic activities expand and when inputs and products are transported more frequently and over longer distances. The overall environmental impact may be positive or negative, depending on the prevailing circumstances. ${ }^{20}$

Likewise, there is a considerable body of research on the effect of the stringency of national policies on international competitiveness and investment decisions. ${ }^{21}$ Those embracing the 'race to the bottom' hypothesis argue that international policy competition drives polluting economic activities to 'pollution havens' (i.e., countries with lax environmental regimes), leading to a policy competition in which countries structurally decrease their environmental standards to attract or keep business within their national borders. According to the 'regulatory chill' hypothesis, states refrain from adopting more stringent regulation in order not to deter actual and potential investors. By contrast, the 'race to the top' hypothesis holds that stringent product standards in certain countries are increasingly being exported, especially by multinational companies diffusing the company-wide enforcement of stringent standards in order to reap economies of scale or preserve a favourable corporate or brand image.

Another strand of research has focused on governance issues. Some argue that globalisation has eroded the formal power of national governments, not only in industrialised countries but also and especially in developing countries. ${ }^{22}$ In their view, power has shifted from states, which used to operate at the regulatory apex, to multinational companies, which now

\footnotetext{
${ }^{17}$ Hardin, 1968; Kaul et al., 1999; Kölliker, 2002; Tietenberg, 2003.

${ }^{18}$ Birnie and Boyle, 2002.

${ }^{19}$ Antweiler et al., 2001; Copeland and Taylor, 2003; Esty and Gentry, 1997; Frankel and Rose, 2002; IISD and UNEP, 2000; Nordström and Vaughan, 1999; Zarsky, 1999.

20 Jenkins et al., 2003.

${ }^{21}$ Boyce, 2004; Copeland and Taylor, 2003; Esty and Geradin, 1998; Jaffe et al., 1995; Mabey and McNally, 1999; Mani and Wheeler, 1998; OECD, 2002; Vogel, 1995, 1997.

${ }^{22}$ Held et al., 1999; Hertz, 2001; Nayyar, 2002; Ohmae, 1995; Opschoor et al., 1999; Sassen, 1996; Strange, 1996.
} 
control a large share of global trade and which may be subject to privileged tax and regulation arrangements. Some have argued that private - profit or not-for-profit - organisations may assume, or have taken over, formerly public environmental roles. Under the banner of 'sustainable business' or 'corporate social responsibility', business organisations may take environmentally benign actions or engage in global self-regulation, for example, through environmental management standards such as ISO $14001 .^{23}$ Alternatively, civil society, often taking concerted action through NGOs and increasingly organised on a regional or global scale, ${ }^{24}$ may take on a prominent role in 'civilising' globalisation, in order to make economic developments more compatible with social and environmental imperatives or even have them reinforce one another. ${ }^{25}$ Hybrid forms here include governance modes such as 'voluntary agreements' between industry and government $^{26}$ and 'public-private partnerships' involving governments, companies, and NGOs. ${ }^{27}$ Others advocate a global environmental government, $^{28}$ arguing that, since many environmental issues are transboundary or global in nature, only a global institute can coordinate national actions and internalise national externalities. Yet others recognise the need for global or regional action but argue that national governments will remain the governing institutions. ${ }^{29}$ International environmental regimes of cooperating states may then be effective in solving global or regional collective action problems.

\section{STRUCTURE AND SYNOPSIS}

Each of the five parts of this book deals with specific elements of the central topic. Part I has a strong conceptual focus, elucidating theories and terminology pertaining to major aspects of globalisation and environmental policy. Besides, it sketches recent empirical developments to provide the reader with the latest state of affairs. Part II explores different societal perspectives and presents contributions by representatives from the business and civic sectors providing viewpoints of major societal constituencies.

${ }^{23}$ Brunsson and Jacobsson, 2000; Cooperrider and Dutton, 1999; Cutler et al., 1999; Holliday et al., 2002; Powell and Clemens, 1998; Winsemius and Guntram, 2002.

${ }^{24}$ Anheier et al., 2001; Arts, 1998; Florini, 2000.

${ }^{25}$ Dunning, 2003; Etzioni, 1990; Florini, 2003; Giddens, 2001; Sklair, 2002; Spaargaren et al., 2000; Van Seters et al., 2003.

${ }^{26}$ Carraro and Lévêque, 1999; Mol et al., 2000; OECD, 2003.

${ }^{27}$ Holliday et al., 2002; Osborne, 2000; Reinicke, 1998; Rischard, 2002; Warner and Sullivan, 2004.

${ }^{28}$ Esty and Ivanova, 2002; Group of Lisbon, 1993; Sandel, 1996; UNDP, 1999.

${ }^{29}$ Barrett, 2003; European Commission, 2004; Gray, 1999; Haas et al., 1993; Kaul et al., 2003; Young, 1994, 1999. 
Where the previous part describes and analyses the behaviour of companies and NGOs, often from an academic perspective, we also wished to let these societal actors, who shape or affect processes of globalisation and environmental policy, speak for themselves. Parts III and IV consist of case studies, the former dealing with global or regional influences on domestic environmental policies, and the latter focusing on national contributions to global or regional forums. The final part (V) provides challenging views of new possible avenues for more effective national, international, or supranational governance of environmental issues.

The different parts and chapters are self-contained. They can be understood independently without relying on preceding parts and chapters, though the reader may assimilate their contents more easily by adhering to the order of the book. It may be especially helpful to take in the conceptual frames traced in Part I before proceeding to other parts. For reasons of convenience, a short summary has been provided at the start of each chapter, allowing the reader to catch the chapter's essence at a glance. While all authors received the same guidelines pertaining to the structure and contents of their contributions, ${ }^{30}$ the wide range of topics, levels, and perspectives has unavoidably led to a measure of heterogeneity in the form and substance of the different chapters.

Tom Jones kicks off Part I with an overview of major conceptual relations between globalisation and national environmental policy (Chapter 2). He also sketches recent trends in economic globalisation, discusses empirical implications for national regimes, and concludes that economic and environmental imperatives can be (made) compatible.

The important issue of national incentives for action is central to Alkuin Kölliker's contribution (Chapter 3). He identifies different types of environmental goods and different trade effects, and argues that their combined effect predicts governmental responses.

Pedro Conceição and Inge Kaul then focus on global public goods, whose collective availability and non-rivalry extend to the global level (Chapter 4). In their view, the nature of many public goods is not technically given but shaped by human perspectives and actions. They also discuss and contextualise different possibilities for financing global environmental actions.

Marion Jansen and Alexander Keck discuss at length the crucial relationship between multinational trade regulations and the discretionary possibilities and constraints of national environmental policies (Chapter 5).

\footnotetext{
${ }^{30}$ Guidelines included: delimitation of topic, definition of key terms, description and analysis of the past (10-20 most recent years) and present situation, approach taken to cope with recent changes, and future developments.
} 
They argue that environmental actions that distort free international trade are not necessarily illicit, though WTO jurisprudence leaves considerable uncertainty as to the acceptability of specific national measures.

René Kemp, Luc Soete, and Rifka Weehuizen discuss policies geared towards environmentally benign innovations (Chapter 6). They describe national innovation policy instruments and their context specificity and argue that globalisation has engendered a governance void, which should be filled by international NGOs.

The contribution by Kees Zoeteman and Eric Harkink focuses on national and corporate sustainability attitudes (Chapter 7). Drawing on a study of two sectors, they point out salient parallels between the attitudes of multinational companies and their home countries.

Gert Spaargaren and Susan Martens highlight the role of citizenconsumers in a globalised setting (Chapter 8). They review literature on ecological citizenship, sustainable consumption, and global civil society. Referring to lifestyle studies, they argue that national environmental policies can be effective if different aspects of citizen-consumer behaviour are considered simultaneously.

The focus then shifts to the interaction between local and central levels of environmental decision-making (Chapter 9). David Vogel, Michael Toffel, and Diahanna Post compare regulative interactions in the EU and the United States (US) in three environmental areas. They conclude that national or state governments can play an important role when diffusing their stringent regimes through federal regulations.

The final contribution of this part (Chapter 10) deals with globalisation and environmental governance in developing countries. Hans Opschoor discusses sustainable development, globalisation, institutions, and types of agents. Focusing on Africa, he argues that the lack of effective governance in developing countries can be compensated to some extent by an active role of civil society.

Part II consists of three contributions by business representatives and two by NGO leaders. Björn Stigson and Britta Rendlen make a case for sustainable business (Chapter 11). They describe the role of the World Business Council for Sustainable Development (WBCSD) in this process and indicate how government and business can contribute to the realisation of sustainable development.

Jan Hol from Nuon, a major Dutch energy supplier, then discusses the success factors in renewable energy in the Netherlands (Chapter 12). He argues that the prospects are dim in a liberalised European energy market and highlights Nuon's strategic response to liberalisation. 
Chris Dutilh describes how and why the multinational Unilever company is involved in sustainable business operations (Chapter 13). He identifies different types of actors, highlights the difference between consumers and citizens, and underscores that government policy should be geared towards bridging the gap between the two.

According to Claude Martin, globalisation has threatened the environment (Chapter 14). He indicates how a globally operating NGO like WWF has addressed this challenge and pleads for cooperative platforms such as partnerships.

In order to defend environmental interests at the EU level, local NGOs have joined forces through the European Environmental Bureau (EEB, Chapter 15). John Hontelez explains the modus operandi of the EEB and argues that the best way of warranting environmental interests is to anchor them into European legislation.

Part III covers our first set of case studies, dealing with the impact of globalisation and regionalisation on domestic environmental policies. Maarten Arentsen and Theo de Bruijn discuss the interactions of EU regulations and Dutch national policy for four energy dossiers (Chapter 16). They conclude that a country's relative power position and international similarity of viewpoints are important determinants of national discretion.

Saskia Ozinga and Nicole Gérard argue that globalisation has aggravated the problem of illegal logging (Chapter 17). They explore possible remedies and conclude that more targeted regulation and independent monitoring would help to reduce this important problem.

Joost van Kasteren points to the scale-up effects of globalisation, which has rendered the development and marketing of environmentally benign pesticides for a small market such as the Netherlands no longer attractive (Chapter 18). While the Dutch government is facing not only these economic but also regulative restrictions at the supranational level (EU, WTO), several national policy options may render crop protection more environmentfriendly.

Henk Massink, Gerard van Dijk, Niek Hazendonk, and Jan van Vliet provide a detailed account of the qualitative and quantitative changes in Dutch agriculture and the local environment in connection with free global trade (Chapter 19). They conclude that the intensification and scaling-up of agricultural production has led to reduced biodiversity and to landscape changes, and that the national government has several options to offset the negative environmental consequences.

Part IV turns to national interventions in the international arena. Sietske Veenman and Duncan Liefferink analyse the influence of three proactive 
countries on EU climate policies (Chapter 20). They conclude that these countries proceed differently in terms of the directness of their approach and the purposefulness of their influence and that they may combine different strategies.

Ludwig Krämer discusses the functioning, achievements, and shortcomings of the European Community's environmental policy (Chapter 21). He argues that a more centralised system would not have led to improved environmental performance because - against the backdrop of national implementation differences - environmental results depend essentially on the political will to act.

The Organisation for Economic Co-operation and Development (OECD) has elaborated a joint system for testing and registering new chemicals (Chapter 22). Rob Visser argues that, when data obtained in one country are also recognised in other (OECD) countries, as occurs in the chemicals system, important advantages accrue to different societal strata.

Frank Wijen and Kees Zoeteman analyse the strengths and weaknesses of the Kyoto climate regime (Chapter 23). After exploring four scenarios for future political constellations and indicating possibilities for creating leverage, they conclude that more appropriate incentives should be built into future climate policies.

The final part (V) bridges the present and the future. Daniel Esty and Maria Ivanova address environmental protection from a global governance perspective (Chapter 24). After discussing interactions between economic globalisation and environmental protection, they make a case for a global environment mechanism: a light institutional superstructure drawing on public policy networks and applying modern information technology.

Charlotte Streck's contribution is devoted to the different types of international policy networks in which national governments are involved (Chapter 25). She discusses the opportunities and threats of global public policy networks and argues that these may constitute an effective complementary governance mechanism.

According to Konrad von Moltke, economic globalisation and environmental globalisation, though both governed by different rules, are intertwined (Chapter 26). The challenge is to design international institutions that consider environmental and economic imperatives in a more integrated fashion.

Finally, Pieter Winsemius reflects on the impact of different schools of public administration on past and present environmental policies in the Netherlands (Chapter 27). He then argues that a small country can have a significant impact on the international arena by creating a breeding ground for environmental NGOs. 


\section{OUTCOMES AND FUTURE DIRECTIONS}

While the richness and specificity of the different chapters does not allow for shorthand, facile conclusions, some connecting threads can be woven. Findings highlighted by several authors and complementarities between various contributions may be summarised under the following headings. ${ }^{31}$

\section{The Delicate, Multifaceted Relation between Ecology and the Economy}

Generally speaking, there is no statistical evidence of relations between the globalisation of economic activities and positive or negative environmental changes. While hard-and-fast statements should be avoided because causalities are very hard to establish, the negative effects of international trade and foreign direct investment (FDI) on the environment have sometimes been overstressed, as has been the presumed negative impact of environmental measures on economic development. ${ }^{32}$ Global economic activities may adversely affect the environment, ${ }^{33}$ but this may be outweighed by the regional or global diffusion of stringent local environmental regimes. ${ }^{34}$ In any case, we need better assessment and communication of the impact of trade and investment on the environment, on the one hand, and of the competitive effects of national environmental regulations, on the other hand. ${ }^{35}$ We may conclude, therefore, that the pursuit of economic and environmental objectives does not necessarily involve trade-offs.

Economic globalisation and environmental protection can be made compatible if a number of conditions are met: ${ }^{36}$

- Trade, FDI, and environmental policies pull in the same direction and create synergies, for example, by abolishing those subsidies that lead to trade distortion and environmental disruption, and by promoting the international trade of environment-friendly products.

- Environmental externalities are internalised, so that costs and benefits are allocated correctly, in particular by applying full-cost accounting.

\footnotetext{
${ }^{31}$ The references in this section concern arguments made by the contributors to this volume.

32 Jones.

${ }^{33}$ Ozinga and Gerard; Van Kasteren.

${ }^{34}$ Vogel et al.

35 Jones; Kölliker.

36 Jones; Martin; Stigson and Rendlen; Von Moltke.
} 
- Environmental policies are in place timely, implying that polluting now while generating growth and cleaning up later is not a sustainable strategy.

Yet, conflicts may arise between economic and environmental policies. Environmental regulations - particularly those developed by virtue of the subsidiarity principle (i.e., national discretion to regulate issues that do not necessarily call for supranational measures) - are often tailored to local circumstances and may clash with free-trade imperatives, which call for a uniform regulative framework. $^{37}$ As economic objectives are often prioritised, it is important to design environmental policies that have minimal trade effects. ${ }^{38}$ However, the fact that national environmental regulations distort international trade does not necessarily involve rejection of the environmental rules: if they serve environmental objectives that are important both ecologically and in relation to the economic costs incurred, and if there are no alternatives with less unfavourable economic effects, the WTO may authorise them. ${ }^{39}$

Local or national environmental regimes may spill over to the federal level or to other countries. Evidence of both positive and negative effects is provided. Several authors show instances of a 'race to the bottom' ${ }^{40}$ In their views and studies, regionalisation or globalisation leads to unleashed market forces that do not allow for environmental considerations and render scalingup inevitable. As a result, the environment is harmed: more fossil fuels are being exploited, biodiversity is increasingly reduced, the illegal logging of tropical forests is aggravated, and environment-friendly pesticides for small markets fail to be developed.

By contrast, there is also evidence of a 'race to the top' in the US and the $\mathrm{EU} .^{41}$ Stringent local standards in proactive states spread to other states via the central level, especially in the EU. However, a further tightening of EU environmental regulations relies on the optimistic assumption that there is the political will to do so. ${ }^{42}$ One way of raising environmental performance is to stimulate the diffusion of environment-friendly technologies, in which innovation policy instruments should be tailored to the prevailing circumstances. ${ }^{43}$ Stringent environmental standards may also spread through private actors: proactive multinational companies (such as Unilever) may set corporate standards that apply worldwide, for all their subsidiaries. ${ }^{44}$

${ }^{37}$ Arentsen and De Bruijn; Krämer; Von Moltke.

${ }^{38}$ Kölliker.

39 Jansen and Keck.

${ }^{40} \mathrm{Hol}$; Martin; Ozinga and Gerard; Van Kasteren.

${ }^{41}$ Krämer; Vogel et al.

${ }^{42}$ Krämer.

${ }^{43}$ Kemp et al.

${ }^{44}$ Dutilh; Stigson and Rendlen. 
These empirical findings and a literature review ${ }^{45}$ lead us to conclude that national environmental standards tighten up if:

- There is the political will to protect the environment.

- Civil society, company head offices, and politicians expect or demand higher standards.

- Non-environmental aspects (such as access to inputs or markets and ease of governance) dominate over (the costs of) environmental standards in business location decisions.

- Market demands or government regulations force global business to engage in technological innovation, which is subsequently applied worldwide to exploit economies of scale.

- NGOs pressurise private companies - for example, by boycotting brands or companies - in order to compensate for the relative absence of the state.

A systematic solution for the tension between trade liberalisation and environmental protection is proposed in two different directions. One possibility is to reform the WTO in such a way that environmental concerns are more fully integrated into economic decisions. ${ }^{46}$ The other approach is to negotiate and facilitate environmental issues in a specialised World Environment Mechanism. ${ }^{47}$ The former approach would seem to hold out better perspectives in the short term, although environmental problems are often more complex than trade issues.

\section{Changes in Domestic Environmental Issues}

Once industrialised countries have solved or contained their local problems such as soil pollution, the more persistent international environmental problems remain an item on the political agenda. While domestic problems with an international character such as international waste transports, transboundary water pollution, and climate change have been around for a long time, national governments are now facing new opportunities and constraints in solving them. For example, national governments can impact the EU agenda; at the same time, they see their discretion reduced through imposed EU legislation. ${ }^{48}$

Collective action is hazardous, especially at the international level. Yet, transboundary problems of a public or semi-public nature must be addressed

\footnotetext{
45 Jones.

${ }^{46}$ Jansen and Keck; Martin; Von Moltke.

${ }^{47}$ Esty and Ivanova.

${ }^{48}$ Arentsen and De Bruijn; Veenman and Liefferink.
} 
at the regional or global level, ${ }^{49}$ in which it is important to note that the nature of environmental problems is amenable to human interpretation. ${ }^{50}$

Though some transboundary environmental problems can and should be solved differently in a globalised world, some domestic problems have been created or aggravated by globalisation. Free trade may lead to higher production and consumption levels, scaling-up, and the geographic reallocation of activities, which, in their turn, may affect the national environment. ${ }^{51}$ Moreover, globalisation has accelerated the exploitation of precious natural resources such as tropical forests and has hampered their environmentally sound management. ${ }^{52}$ Furthermore, global suppliers may be discouraged from supplying environment-friendly products to small markets. ${ }^{53}$ Problems that have been engendered or aggravated by globalisation are much more difficult to solve, especially when important economic forces are at work, as in the case of agriculture, natural resources, and chemicals.

\section{Changes in Governance Mechanisms}

Globalisation has led to important changes in the distribution of power and governance modes. Some important developments are discussed below.

\section{New position of societal actors}

Multinational companies increasingly operate in regional clusters and global alliances. The WBCSD is a prominent example of a cooperative platform of environmentally proactive companies. ${ }^{54}$ Local NGOs have also joined forces in international networks, such as the EEB, in response to the shift of regulative power from local and national levels to the supranational level, such as the EU. ${ }^{55}$ Other NGOs (such as WWF) are global players. They focus on global environmental problems, even if these often involve local action. ${ }^{56}$ The behaviour of individual citizens is susceptible to global influences. ${ }^{57}$ Citizens also organise themselves increasingly on a global scale, sometimes only for one-off events. ${ }^{58}$ These - ephemeral or more structural civil networks are constructed with the aid of the internet and attract huge

\footnotetext{
${ }^{49}$ Kölliker.

${ }^{50}$ Conceição and Kaul.

${ }^{51}$ Massink et al.

52 Ozinga and Gerard.

${ }^{53}$ Van Kasteren.

${ }^{54}$ Stigson and Rendlen.

55 Hontelez.

${ }^{56}$ Martin.

${ }^{57}$ Spaargaren and Martens.

58 Winsemius.
} 
media attention. The negative publicity and boycotts engendered by (perceived) local environmental missteps have the potential to negatively affect the global corporate image and market performance of multinational companies. $^{59}$

\section{New supranational forums}

The process in which many societal actors increasingly move to international arenas for information exchange, negotiation, policy-making, and enforcement - which are beyond direct national control - has put pressure on national governments to add a networking role to their traditional roles as regulators and supervisors. There is a multitude of formal and informal networks in which governments seek alliances for their specific interests and exert influence in the power centres of supranational organisations such as the EU and the United Nations (UN). ${ }^{60}$ The effectiveness of relational networks may benefit from a central organism that facilitates and coordinates actions outside extant power structures. ${ }^{61}$

Apart from political interactions in the more classic 'public-public' policy networks, ${ }^{62}$ governments increasingly participate in 'public-private' networks to exchange information, share facilities, and jointly manage products, processes, or regions. Such platforms for governments, companies, and NGOs can be effective if they meet certain conditions for cooperation, including expected benefits for all parties involved, willingness to realise common goals, and readiness to make individual resources collectively available. $^{63}$

\section{Growing complexity and reduced impact of nation states}

Increasing numbers of international and supranational directives, conventions, and related regulations impose more and more obligations on individual states and limit their sovereignty. ${ }^{64}$ Furthermore, because ever more state and non-state actors are involved in consultation and decisionmaking, the impact of small and medium-sized individual states on the development of international policy is continuously dwindling. ${ }^{65}$

Hence, new strategies are needed for proactive governments to enhance the impact of their initiatives. Strategies to achieve good results include prioritisation and linkage of issues, coalition formation with other delegations, domestic preparation of package deals with other ministries, and

${ }^{59}$ Dutilh; Ozinga and Gerard; Zoeteman and Harkink.

${ }^{60}$ Streck.

${ }^{61}$ Esty and Ivanova.

62 Arentsen and De Bruijn; Veenman and Liefferink; Vogel et al.

${ }^{63}$ Conceição and Kaul; Martin; Opschoor; Streck; Visser; Zoeteman and Harkink.

${ }^{64}$ Arentsen and De Bruijn; Jansen and Keck; Krämer; Van Kasteren.

${ }^{65}$ Hol; Hontelez; Winsemius. 
investment in scientific knowledge. ${ }^{66}$ Economy-environment compatibilities and trade-offs should be analysed in advance, and a sufficiently independent position of environmental interests should be aimed at in economy-driven international or supranational negotiations. ${ }^{67}$

Governments can also develop joint initiatives with like-minded nations and global companies. ${ }^{68}$ Such initiatives may include agreements on more sustainable performance in combination with export-credit guarantees, cofinancing, eco-labelling, and public-performance rating. ${ }^{69}$ Grants to certified companies for managing global commons could also be part of new arrangements.

\section{Coping with Reduced Sovereignty}

The infringement of globalisation on national discretion has led to the following changes with respect to governments' environmental policies.

\section{Transparency and accountability}

The development of more international and supranational policies has increasingly turned nation states into the implementers of international mandates. ${ }^{70}$ The primacy has shifted away from national instruments, such as command-and-control measures and taxes, to regional or global regulations, such as EU directives, and 'soft law', like OECD guidelines, aiming - among other things - at enhancing transparency and polluter accountability. National authorities, therefore, are transiting from a directing to a reporting role. This requires:

- Increasing transparency by streamlining the reporting obligations of local governmental bodies and business organisations, as supranational authorities will monitor the incidence of inconsistencies, and reporting results may generate novel or altered obligations.

- Enhancing accountability by adopting and enforcing standards for environment-friendly behaviour and by developing novel policy instruments that are flexible and cost-effective.

- Improving the operational capacity of national and local governmental bodies to implement national commitments.

\footnotetext{
${ }^{66}$ Veenman and Liefferink; Wijen and Zoeteman; Winsemius.

${ }^{67}$ Esty and Ivanova; Jones; Kölliker; Von Moltke.

${ }^{68}$ Zoeteman and Harkink.

${ }^{69}$ Conceição and Kaul; Ozinga and Gerard.

${ }^{70}$ Arentsen and De Bruijn; Hol; Hontelez; Jansen and Keck; Krämer; Van Kasteren.
} 
- Generating national mechanisms to prevent non-compliance sanctions to which countries may be subjected, for example, by imposing carbon dioxide emission caps on domestic industries.

When nation states have recurrently experienced supervision by higher authorities and the threat of impending sanctions, they may anticipate the collective supervision of the implementation of international mandates by setting their ambition levels below those they would otherwise strive for. National environmental authorities may counteract pressures for a more conservative approach by being sensitive to knowledge provided by progressive colleagues in other countries and by exchanging information on the availability of cost-effective solutions that show the feasibility of ambitious objectives, such as the EU's 'open method of coordination'.

\section{Promotion of self-enforcing mechanisms}

Many international agreements are not respected because the actors involved or targets aimed at do not face the appropriate incentives. This goes particularly for global public and common pool environmental resources. ${ }^{71}$ In the absence of an effective world government, governments may then look for self-enforcing mechanisms. Market forces can sometimes be structured in ways that stimulate environment-friendly solutions, for example, through eco-labelling. ${ }^{72}$ If this is not the case, global public agreements should be conceived in such a way that it is in the nation states' own interest to participate, for example, because participation provides access to restricted markets. If public goods can be turned into club goods that are non-rival in nature and available only to participants, collective action problems can be reduced or even solved. ${ }^{73}$ A third course of action is to develop instruments that are applicable both domestically and internationally, and that allow for cost-effective solutions while achieving ambitious environmental objectives, for example, through internationally tradable permits or regional covenants.

\section{Need for improved communication with citizens}

When the physical or psychic distance between supranational policy-makers and those experiencing their impacts widens, states may lose their legitimacy towards their own citizens. Realising international agreements may involve making compromises and having to give up some national or local political priorities, which may give rise to general feelings of alienation. The low degree of trust many citizens have in their governments and in supranational

\footnotetext{
${ }^{71}$ Conceição and Kaul; Kölliker.

72 Jones; Martin; Stigson and Rendlen.

${ }^{73}$ Conceição and Kaul; Wijen and Zoeteman.
} 
administrative bodies is an indication of this phenomenon. ${ }^{74}$ Indeed, many citizens feel that their government's environmental policies do not match their lifestyles. ${ }^{75}$ While there may be good reason to challenge the sovereignty of citizen-consumers, national governments should also communicate supranational decisions to their citizens more actively and voice idiosyncratic preferences of local or national constituencies at the international level. ${ }^{76}$ To enhance communication, efficient technologies like the internet could be used to inform citizens about the substance and form of supranational or international policies, national ambitions, and local repercussions.

\section{Prospects for Environmental Policy Instruments}

Conventional public policy instruments are licences, standards, levies, subsidies, taxes, and tradable permits. To avoid competitive distortions for domestic industries and to avoid supranational sanctioning of unachieved targets, nations may choose, or be forced, to downgrade their ambition levels and use the conventional toolkit sparingly. ${ }^{77}$ Yet, we have also witnessed the collective upgrading of many environmental standards in the EU and the US. ${ }^{78}$ It is unclear whether this ratcheting-up process will continue. The US presently lacks the willingness at the federal level to endorse nation-wide dissemination of stringent local standards, while no EU member state is currently pushing hard to get stringent national norms spilled over to other European countries.

In these circumstances, proactive national governments can still take a number of actions:

- Avoid national participation in a race to the bottom, for example, by adhering to internationally agreed process standards. ${ }^{79}$

- Stimulate race-to-the-top effects by supporting regional or global product standards such as chemicals classifications and international eco-labelling systems. ${ }^{80}$

- Foster the development of NGOs to expose environmental evils, ${ }^{81}$ act as countervailing powers, ${ }^{82}$ create international leverage, ${ }^{83}$ and/or fill a

\footnotetext{
${ }^{74}$ Hontelez; Martin.

${ }^{75}$ Spaargaren and Martens.

${ }^{76}$ Dutilh; Spaargaren and Martens.

${ }^{77}$ Hol; Martin; Ozinga and Gerard; Van Kasteren.

${ }^{78}$ Krämer; Vogel et al.

${ }^{79}$ Massink et al.

${ }^{80}$ Martin; Ozinga and Gerard; Visser; Vogel et al.

${ }^{81}$ Ozinga and Gerard.

${ }^{82}$ Opschoor.
} 
global governance void. ${ }^{84}$ NGOs themselves should also be critically monitored to make sure that their actions are in the best interest of the environment.

- Create and foster informal networks and partnerships around 'coalitions of the willing', involving public and private actors at the local, national, regional, and global levels. ${ }^{85}$

- Promote voluntary codes of conduct by favouring or rewarding companies that have an environmental code certification and stimulate multinational companies whose headquarters are within the national territory to adopt universal environmental standards for all their subsidiaries. ${ }^{86}$

- Tailor 'green' innovation policy instruments to the prevailing circumstances, anticipate economies of scale in technological innovations, and bridge the financial gap between present investments and future payoffs. $^{87}$

- Link environmental policies to other, high-priority policy areas requiring the same types of measures, for example, focusing on public health to reduce air pollution. ${ }^{88}$

Finally, there are many ways to develop the entrepreneurial role of small and medium-sized nations, including: (1) the development of leadership as a gobetween for larger states and the use of convening and secretariat functions; (2) the promotion of corporate social responsibility via multinational companies and NGOs operating within the national borders by providing environmental venture capital, think tanks, and centres of excellence. ${ }^{89}$

\section{Balancing Globalisation and National Environmental Policy}

Globalisation has enhanced, if not created, an intertwining of issues, actors, and states. At the same time, the centres of gravity have shifted beyond national borders: environmental decisions are increasingly being taken by supranational organisations such as the EU and the WTO and by large multinational companies. In order to develop and implement effective environmental policies and to maintain or restore legitimacy towards their citizens, governments need to take appropriate and concerted action, both domestically and internationally. In choosing the appropriate administrative level, governments should not think primarily in terms of the nature of a

${ }^{83}$ Winsemius.

${ }^{84}$ Kemp et al.

${ }^{85}$ Esty and Ivanova; Martin; Streck; Zoeteman and Harkink.

${ }^{86}$ Martin; Stigson and Rendlen; Zoeteman and Harkink.

${ }^{87}$ Kemp et al.

${ }^{88}$ Wijen and Zoeteman.

${ }^{89}$ Winsemius. 
problem itself, for example, a global issue such as climate change, but rather in terms of the forum where solutions to this problem could be most effectively addressed, which might initially involve a regional regime for the climate issue.

National governments are losing classic policy options: long-term targets are controversial in the international arena; subsidies may have to be restricted to avoid international trade distortions; levies and taxes are more difficult to effectuate; and national covenants may fit poorly with international accountability imperatives. There is also less room for new initiatives in areas that have already been regulated in an international framework. Yet, new partnerships may emerge, and innovative policy instruments can be developed. This requires an entrepreneurial role for public authorities to use the opportunities that globalisation offers.

Not all policy areas are equally vulnerable to loss of ambition. Special concern is needed for:

- Environmental issues lacking owners: global commons such as oceans, ice caps, climate, and the ozone layer. ${ }^{90}$

- Natural resources representing large economic interests, for example, the trade in rare species or tropical timber, which are reflected in international economic agreements that lack accompanying environmental measures. ${ }^{91}$

- Environmental problems causing local harm but requiring large-scale technological solutions, such as low-emission vehicles and crop protection. $^{92}$

- Environmental issues requiring international enforcement of measures, for example, mitigating climate change. ${ }^{93}$

- Problems lacking environmental champions who implement local measures and push towards acceptance of progressive policies at the central level, such as Germany in the EU and California in the US. ${ }^{94}$

- Environmental issues sensitive to corruption, such as the exploitation of natural resources, especially in developing countries. ${ }^{95}$

Given these changes and the limited possibilities for national governments to resist the effects of globalisation, we need shifts towards instruments that can be used nationally. Such shifts may include:

\footnotetext{
${ }^{90}$ Conceição and Kaul; Kölliker; Ozinga and Gerard; Wijen and Zoeteman.

${ }^{91}$ Martin; Ozinga and Gerard.

${ }^{92}$ Conceição and Kaul; Van Kasteren; Vogel et al.

${ }^{93}$ Kölliker; Wijen and Zoeteman.

${ }^{94}$ Krämer; Veenman and Liefferink; Vogel et al.

95 Opschoor; Ozinga and Gerard.
} 
- The reduced use of those levies and other instruments that distort international markets. $^{96}$

- Increased cross-border cooperation with foreign governments, multinational companies, and global NGOs. ${ }^{97}$

- Exploration of and engagement in partnerships. ${ }^{98}$

- Increased use of higher-level (i.e., federal, regional, or global) standards instead of lower-level (i.e., national or local) standards. ${ }^{99}$

- Greater emphasis on the education of and communication with civil society. $^{100}$

- Promotion of self-regulation and private initiatives with environmental robustness. ${ }^{101}$

- Stimulating the application of self-enforcing mechanisms in international agreements. $^{102}$

As outlined above, the commensurability of governance levels and the compatibility of different areas are of central importance. Figures 1.1 and 1.2 recapitulate - in a strongly simplified way, for the sake of clarity interactions between globalisation and national environmental policies with respect to these issues. Figure 1.1 represents the situation in which nation states are relatively autonomous. The national government operates at the top of the regulative hierarchy. It has a high degree of discretion to develop national environmental policy, which is often enforced through legislation and other types of regulation, such as voluntary agreements. These policies are then implemented by local authorities, who issue and control environmental licences to local companies. Civil society, often organised through local NGOs, exerts moral pressure on local and national governments as voting citizens and economic influence on local companies as employees and consumers. Business lobbies the national government in order to avoid too stringent or costly regulations. While supranational organisations, such as the UN, exist, their influence is relatively limited. In this situation, the dominant influence - represented by thick arrows - is of a formal nature and goes from the national government via local government to business: public authorities largely impose command-and-control measures on business. The focus is predominantly on local environmental problems on the basis of a local cost-benefit analysis, as these can be addressed by the competent authorities; transboundary environmental issues

${ }^{96}$ Jansen and Keck; Jones; Stigson and Rendlen.

${ }^{97}$ Conceição and Kaul; Martin; Visser; Zoeteman and Harkink.

${ }^{98}$ Dutilh; Martin; Opschoor; Streck.

${ }^{99}$ Visser; Vogel et al.; Wijen and Zoeteman.

${ }^{100}$ Dutilh; Spaargaren and Martens.

${ }^{101}$ Jones; Stigson and Rendlen; Zoeteman and Harkink.

${ }^{102}$ Wijen and Zoeteman. 
are largely taken for granted. The sovereignty situation is characterised by a relatively high degree of convergence between jurisdictional competence, the level of political influence, and the scale of economic activities, which are predominantly located at the national and sub-national levels.

Globalisation dramatically alters the arena in which environmental policy is developed and implemented (Figure 1.2). National borders have become much more permeable. Business has internationalised its activities and footloose multinational companies are subject to different national regimes. Local business lobbies national government and - via supranational trade associations - supranational organisations to stress the importance of a 'level

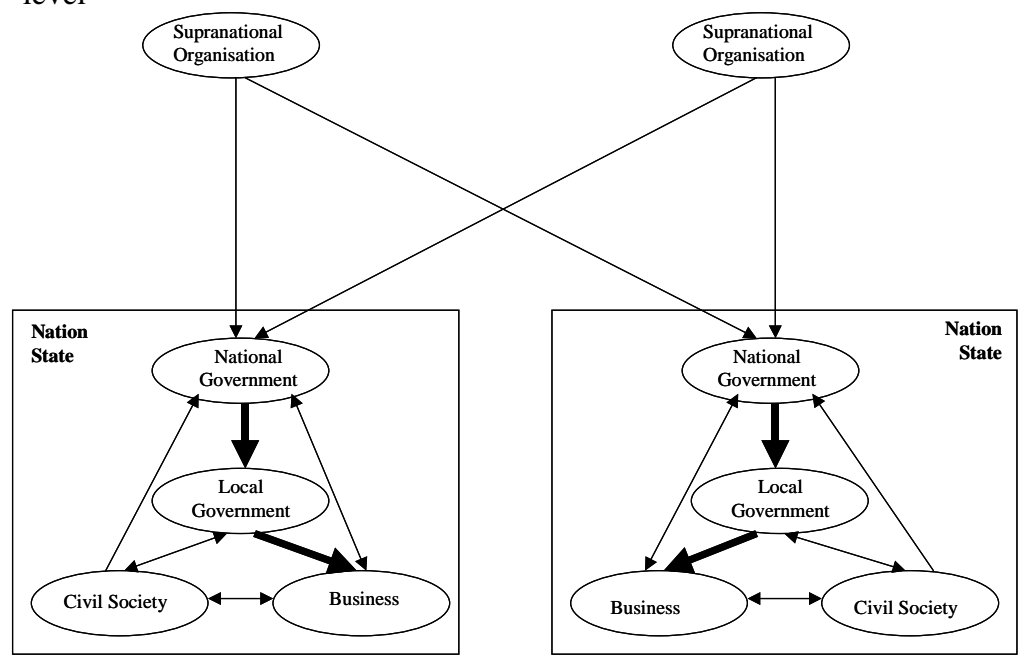

Figure 1.1 Influences in the national sovereignty system

playing field', i.e., the absence of different competitive positions owing to divergent environmental regulations. Civil society still has contacts with local companies as well as local and national governments, but consists increasing-ly of global citizens who raise their voice against unacceptable behaviour of foreign governments, citizens, and companies, often orchestrated by supranational NGOs. Consumers increasingly purchase products from around the world, whose marketing is often supported by global brands. The national government has lost a considerable degree of control 'from below', as the behaviour of its subjects is increasingly driven by foreign influences. At the same time, the national government's formal power is also reduced 'from above': supranational organisations (the WTO and the EU, in particular) constrain the discretion of the national government 
through multilateral regulations. While the national government can still initiate its own policies, it more often implements multilateral agreements that reflect the divergent interests of a considerable number of countries. Consequently, the national government often becomes a relatively small player in a large arena, while the increased distance between regulators and citizens as well as the increased divergence of interests may cause feelings of alienation. On the basis of 'imported' regulations and its 'own' preferences, the national government then develops and implements environmental policy, its choice of instruments being constrained not only by supranational rules but also by the necessity to consider the international competitiveness of domestic industries.

Local

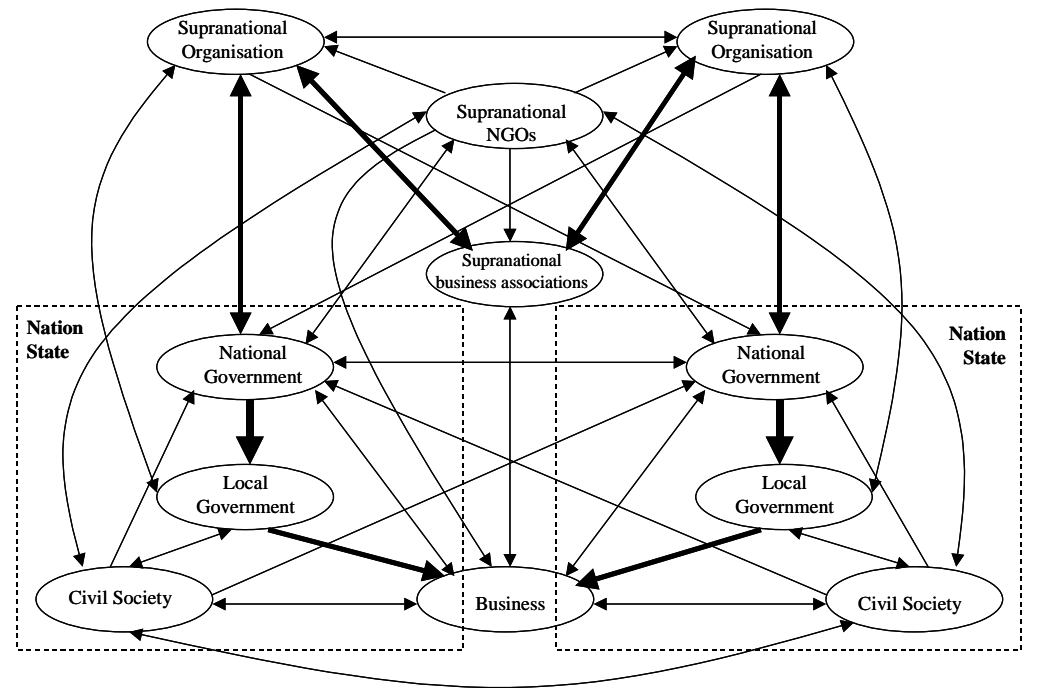

Figure 1.2 Influences in the globalisation system

governments still implement national policy, though they may also have direct contacts with supranational bodies. While national and local governments remain important for companies, the business community increasingly interacts directly with supranational organisations, for example, by lobbying supranational bodies and entering into partnerships with supranational NGOs. The national government has not only lost part of its sovereignty but has also gained new opportunities: it consults, negotiates, and coalesces - through formal and informal contacts - with foreign governments, supranational organisations, multinational companies, and multinational NGOs. These new or intensified contacts enable the 
government to address transboundary, regional, or global environmental problems. Whereas hierarchical relations dominate in the case of national sovereignty, networking governs the globalised arena. Globalisation has brought about an intertwining of foreign and domestic influences. At the same time, with national jurisdiction being constrained by territorial boundaries, and economic, political, and social influences transgressing those boundaries, different spheres of influence are growing more disjunctive. This may hamper environmental protection, especially if states can be played off against one another by powerful economic actors. However, the environment may also benefit from spill-overs of proactive environmental practices and multilateral cooperation. The balance for the environment is contextdependent, in which the conception of governance modes and incentives for different societal actors are of crucial importance.

In conclusion, the studies in this volume show that the impact of globalisation on national environmental policy is indeed huge. While some changes have occurred in a short period, many have taken place more progressively and may have remained unnoticed to many. This book shows the multiple factors and their interactions that have led to actual and desired changes in the ways in which national governments can intervene effectively in the global arena in order to protect the environment.

\section{REFERENCES}

Anheier, H., M. Glasius, and M. Kaldor (eds) (2001), Global Civil Society 2001, Oxford: Oxford University Press.

Antweiler, W., B. Copeland, and S. Taylor (2001), 'Is free trade good for the environment?', American Economic Review, 91(4), 877-908.

Arts, B. (1998), The Political Influence of Global NGOs: Case Studies on the Climate and Biodiversity Conventions, Utrecht: International Books.

Baker, D., G. Epstein, and R. Pollin (eds) (1998), Globalization and Progressive Economic Policy, Cambridge: Cambridge University Press.

Barrett, S. (2003), Environment \& Statecraft: The Strategy of Environmental TreatyMaking, Oxford: Oxford University Press.

Bhagwati, J. (2002), Free Trade Today, Princeton: Princeton University Press.

Birnie, P. and A. Boyle (2002), International Law and the Environment, 2nd ed., Oxford: Oxford University Press.

Boyce, J. (2004), 'Green and brown? Globalization and the environment', Oxford Review of Economic Policy, 20(1), 105-128.

Bromley, D. (ed.) (1995), The Handbook of Environmental Economics, Oxford: Blackwell.

Brunsson, N. and B. Jacobsson (2000), A World of Standards, Oxford: Oxford University Press.

Carraro, C. and F. Lévêque (1999), Voluntary Approaches in Environmental Policy, Dordrecht: Kluwer.

Carson, R. (1962), Silent Spring, Boston: Houghton Mifflin. 
Castells, M. (1996), The Information Age: Economy, Society and Culture: Volume I: The Rise of the Network Society, Malden: Blackwell.

Copeland, B. and S. Taylor (2003), Trade and the Environment: Theory and Evidence, Princeton: Princeton University Press.

Cooperrider, D. and J. Dutton (eds) (1999), Organizational Dimensions of Global Change: No Limits to Cooperation, Thousand Oaks: Sage.

Cutler, C., V. Haufler, and T. Porter (eds) (1999), Private Authority and International Affairs, Albany: State University of New York Press.

Dunning, J. (ed.) (2000), Regions, Globalization, and the Knowledge-Based Economy, Oxford: Oxford University Press.

Dunning, J. (ed.) (2003), Making Globalization Good: The Moral Challenges of Global Capitalism, Oxford: Oxford University Press.

EEA (2003), ‘Europe’s environment: The third assessment: Environmental assessment report no. 10', http://reports.eea.eu.int/environmental_assessment _report_2003_10/en, Copenhagen: European Environment Agency.

Esty, D. and B. Gentry (1997), 'Foreign investment, globalisation, and environment', in OECD, Globalization and Environment: Preliminary Perspectives, Paris: Organisation for Economic Co-operation and Development.

Esty, D. and D. Geradin (1998), 'Environmental protection and international competitiveness', Journal of World Trade, 32(5), 5-46.

Esty, D. and M. Ivanova (eds) (2002), Global Environmental Governance: Options \& Opportunities, New Haven: Yale Center for Environmental Law and Policy.

Etzioni, A. (1990), The Moral Dimension: Toward a New Economics, New York: Free Press.

European Commission (2004), Stimulating Technologies for Sustainable Development: An Environmental Technologies Action Plan for the European Union, COM(2004) 38 final, Brussels: European Commission.

Florini, A. (ed.) (2000), The Third Force: The Rise of Transnational Civil Society, Tokyo: Japan Center for International Exchange.

Florini, A. (2003), The Coming Democracy: New Rules for a New World, Washington DC: Island Press.

Frankel, J. (2000), 'Globalization of the economy', NBER working paper 7858, http:www.nber.org/papers/w7858, Cambridge: National Bureau of Economic Research.

Frankel, J. and A. Rose (2002), 'Is trade good or bad for the environment? Sorting out the causality', NBER working paper 9201, http://www.nber.org/papers/w9201, Cambridge: National Bureau of Economic Research.

Giddens, A. (ed.) (2001), The Global Third Way Debate, Cambridge: Polity Press.

Gray, B. (1999), 'The development of global environmental regimes: Organizing in the absence of authority', in D. Cooperrider and J. Dutton (eds), Organizational Dimensions of Global Change: No Limits to Cooperation, Thousand Oaks: Sage.

Group of Lisbon (1993), Limits to Growth, Lisbon: Gulbenkian Foundation.

Haas, P., R. Keohane, and M. Levy (eds) (1993), Institutions for the Earth: Sources of International Environmental Protection, Cambridge: MIT Press.

Hardin, G. (1968), 'The tragedy of the commons', Science, 162, 1243-1248.

Held, D. (ed.) (2004), A Globalizing World? Culture, Economics, Politics, 2nd ed., London: Routledge.

Held, D. et al. (1999), Global Transformations: Politics, Economics and Culture, Cambridge: Polity Press. 
Hertz, N. (2001), The Silent Takeover: Global Capitalism and the Death of Democracy, London: Heinemann.

Hobsbawm, E. (1975), The Age of Capital, 1848-1875, London: Weidenfeld and Nicolson.

Holliday, C., S. Schmidheiny, and P. Watts (2002), Walking the Talk: The Business Case for Sustainable Development, Sheffield/San Francisco: Greenleaf/BerrettKoehler.

IISD and UNEP (2000), Environment and Trade: A Handbook, Winnipeg/Stevenage: International Institute for Sustainable Development/United Nations Environment Programme.

Inglehart, R. (1997), Modernization and Postmodernization: Cultural, Economic, and Political Change in 43 Societies, Princeton: Princeton University Press.

Jaffe, A., S. Peterson, P. Portney, and R. Stavins (1995), 'Environmental regulation and the competitiveness of U.S. manufacturing: What does the evidence tell us?', Journal of Economic Literature, 33, 132-163.

Jenkins, R., J. Barton, A. Bartzokas, J. Hesselberg, and H. Mereke Knutsen (2003), Environmental Regulation in the New Global Economy: The Impact on Industry and Competitiveness, Cheltenham: Edward Elgar.

Kaul, I., I. Grunberg, and M. Stern (eds) (1999), Global Public Goods: International Cooperation in the $21^{\text {st }}$ Century, New York: Oxford University Press.

Kaul, I., P. Conceição, K. Le Goulven, and R. Mendoza (eds) (2003), Providing Global Public Goods: Managing Globalization, New York: Oxford University Press.

Keohane, R. and J. Nye (1977), Power and Interdependence: World Politics in Transition, Boston: Little and Brown.

Klein, N. (2000), No Logo: No Space, No Choice, No Jobs, London: Flamingo.

Kölliker, A. (2002), The Impact of Flexibility on the Dynamics of European Unification, Dissertation, Florence: European University Institute.

Landes, D. (1998), The Wealth and Poverty of Nations: Why Some Countries are so Rich and Some so Poor, New York: Norton \& Company.

Lechner, F. and J. Boli (eds) (2000), The Globalization Reader, Malden: Blackwell.

Lesser, J., D. Dodds, and R. Zerbe (eds) (1997), Environmental Economics and Policy, Reading: Addison-Wesley.

Levy-Livermore, A. (ed.) (1998), Handbook on the Globalization of the World Economy, Cheltenham: Edward Elgar.

Mabey, N. and R. McNalley (1999), Foreign Direct Investment and the Environment: From Pollution Haven to Sustainable Development, Surrey: WWF UK.

Mäler, K. and J. Vincent (eds) (2003), Handbook of Environmental Economics, Volume I: Environmental Degradation and Institutional Responses, Amsterdam: Elsevier.

Mani, M. and D. Wheeler (1998), 'In search of pollution havens? Dirty industry in the world economy (1960-1995)', Journal of Environment and Development, 7(3), 215-247.

McNeill, J. and W. McNeill (2003), The Human Web: A Bird's-Eye View of World History, New York: Norton \& Company.

Meadows, D., D. Meadows, J. Randers, and W. Behrens (1972), The Limits to Growth: A Report for the Club of Rome's Project on the Predicament of Mankind, London: Earth Island.

Michie, J. (ed.) (2003), The Handbook of Globalisation, Cheltenham: Edward Elgar. 
Mol, A., V. Lauber, and D. Liefferink (eds) (2000), The Voluntary Approach to Environmental Policy: Joint Environmental Approach to Environmental DecisionMaking in Europe, Oxford: Oxford University Press.

Moore, M. (2003), A World without Walls: Freedom, Development, Free Trade, and Global Governance, Cambridge: Cambridge University Press.

Mullard, M. (2004), The Politics of Globalisation and Polarisation, Cheltenham: Edward Elgar.

Nayyar, D. (2002), Governing Globalization: Issues and Institutions, Oxford: Oxford University Press.

Norberg, J. (2003), In Defense of Global Capitalism, Washington, DC: Cato Institute.

Nordström, H. and S. Vaughan (1999), Trade and Environment: Special Studies 4, Geneva: World Trade Organization.

OECD (2002), Environmental Issues in Policy-Based Competition for Investment: A Literature Review, Paris: Organisation for Economic Co-operation and Development.

OECD (2003), Voluntary Approaches for Environmental Policy: Effectiveness, Efficiency and Usage in Policy Mixes, Paris: Organisation for Economic Cooperation and Development.

Ohmae, K. (1995), The End of the Nation-State: The Rise of Regional Economies, London: HarperCollins.

Opschoor, J., K. Button, and P. Nijkamp (eds) (1999), Environmental Economics and Development, Cheltenham: Edward Elgar.

Osborne, S. (ed.) (2000), Public-Private Partnerships: Theory and Practice in International Perspective, London: Routledge.

Powell, W. and E. Clemens (eds) (1998), Private Action and the Public Good, New Haven: Yale University Press.

Reinicke, W. (1998), Global Public Policy Networks: Governing Without Government?, Washington, DC: Brookings Institution Press.

Rischard, J. (2002), High Noon: Twenty Global Problems, Twenty Years to Solve Them, New York: Basic Books.

Rugman, A. (2001), The End of Globalization: A New and Radical Analysis of Globalization and What it Means for Business, London: Random House.

Sandel, M. (1996), Democracy's Discontent: America in Search of a Public Philosophy, Boston: Harvard University Press.

Sassen, S. (1996), Losing Control? Sovereignty in an Age of Globalisation, New York: Columbia University Press.

Schaeffer, R. (2003), Understanding Globalization: The Social Consequences of Political, Economic, and Environmental Change, Lanham: Rowman \& Littlefield.

Scholte, J. (2000), Globalization: A Critical Introduction, Hampshire: Palgrave.

Sklair, L. (2002), Globalization: Capitalism \& its Alternatives, 3rd ed., Oxford: Oxford University Press.

Spaargaren, G., A. Mol, and F. Buttel (eds) (2000), Environment and Global Modernity, London: Sage.

Stiglitz, J. (2002), Globalization and its Discontents, New York: Norton \& Company. Strange, S. (1996), The Retreat of the State: The Diffusion of Power in the World Economy, Cambridge: Cambridge University Press.

Sutherland, W. (2000), The Conservation Handbook: Research, Management and Policy, Oxford: Blackwell.

Tietenberg, T. (2003), Environmental and Natural Resource Economics, Boston: Addison-Wesley. 
Tietenberg, T., K. Button, and P. Nijkamp (eds) (1999), Environmental Instruments and Institutions: Environmental Analysis and Economic Policy, Volume 6, Cheltenham: Edward Elgar.

UNDP (1999), Human Development Report 1999, Oxford: Oxford University Press.

UNEP (2003), 'GEO year book 2003', http://www.unep.org/geo/yearbook/, Nairobi: United Nations Environment Programme.

Van den Bergh, J. (ed.) (1999), Handbook of Environmental and Resource Economics, Cheltenham: Edward Elgar.

Van den Bergh, J. (ed.) (2002), Handbook of Environmental and Resource Economics, Cheltenham: Edward Elgar.

Van Seters, P., B. de Gaay Fortman, and A. de Ruijter (eds) (2003), Globalization and its New Divides: Malcontents, Recipes, and Reform, Amsterdam: Dutch University Press.

Vogel, D. (1995), Trading Up: Consumer and Environmental Regulation in a Global Economy, Cambridge: Harvard University Press.

Vogel, D. (1997), 'Trading up and governing across: Transnational governance and environmental protection', Journal of European Public Policy, 4(4), 556-571.

Wackernagel, M. and W. Rees (1996), Our Ecological Footprint: Reducing Human Impact on the Earth, Gabriola Island: New Society.

Wallerstein, I. (1974), The Modern World-System: Volume I: Capitalist Agriculture and the Origins of the European World-Economy in the Sixteenth Century, New York: Academic Press.

Wallerstein, I. (1980), The Modern World-System: Volume II: Mercantilism and the Consolidation of the European World-Economy, 1600-1750, New York: Academic Press.

Warner, M. and Sullivan, R. (eds) (2004), Putting Partnerships to Work: Strategic Alliances for Development between Government, the Private Sector and Civil Society, Sheffield: Greenleaf.

Waters, M. (2001), Globalization, 2nd ed., London: Routledge.

Winsemius, P. and U. Guntram (2002), A Thousand Shades of Green: Sustainable Strategies for Competitive Advantage, London: Earthscan.

World Economic Forum (2002), '2002 environmental sustainability index', http://www.ciesin.columbia.edu/indicators/ESI, Geneva: World Economic Forum.

Young, O. (1994), International Governance: Protecting the Environment in a Stateless Society, Ithaca: Cornell University Press.

Young, O. (ed.) (1999), The Effectiveness of International Environmental Regimes: Causal Connections and Behavioral Mechanisms, Cambridge: MIT Press.

Zarsky, L. (1999), 'Havens, halos, and spaghetti: Untangling the evidence about foreign direct investment and the environment', in OECD, Globalization and Environment, Paris: Organisation for Economic Co-operation and Development. 